\title{
Determinants of Access to Credit Among Small Scale Irrigation User Farmers in Dangla Woreda, Amhara National Regional State, Ethiopia
}

\author{
Tigist Tesfaye* \\ College of Business and Economics, Bahir dar University \\ Wudu Worku \\ Commercial Bank of Ethiopia, Bahir Dar Ethiopian
}

\begin{abstract}
The main objective of this study is to determine factors affecting access to credit among small scale irrigation user farmers. The study used both primary and secondary data. The primary data were collected through structured interview questionnaire from 329 irrigation user farmers from two kebeles. The sample households selected by using multistage random sampling method. Logistic regression method is applied to examine factors that affect access to credit. Based on the econometrics estimation result, cost of irrigation technology, households attitude towards risk (risk), income from irrigation, lending procedures, repayment period, age of the household (age) and livestock ownership were important factors influencing smallholder farmers access to formal credit in the study area.
\end{abstract}

Keywords: Credit access, Small-scale irrigation, Agriculture finance

DOI: $10.7176 / J E S D / 10-5-08$

Publication date:March $31^{\text {st }} 2019$

\section{Introduction}

Despite progress toward eliminating extreme poverty, Ethiopia remains one of the poorest countries in the world, due to rapid population growth and a low starting base. Services have surpassed agriculture as the principal source of GDP, but Approximately $80 \%$ of the population is still employed in the agricultural sector World Fact Book report (2017). Desta (2004) found that Agriculture in the country is mostly rainfall dependent, small- scale, traditional and subsistence farming with limited access to technology and institutional support services.

The development of small-scale irrigation is one of the major mediation areas to boost agricultural production in the rural parts of the country FAO (2003). In Ethiopia, traditional irrigation was practiced before centuries Bekele et al. (2012). seleshi et al. (undated) Irrigation is practiced in Ethiopia since ancient times producing subsistence food crops. Nevertheless, modern irrigation systems were started in the 1960s with the objective of producing industrial crops in Awash Valley. Dereje and Desale (2016), but modern irrigation began in the 1950s through private and government-owned schemes in the middle Awash Valley and in the 1960s. Farm input supply; including improved seeds Short- and medium term credit is necessary to develop profitable irrigated agriculture Olaf Verheijen (2011). However the financial service contributions to agricultural sector players in Ethiopia face gaps in terms of access to financial services, product quality, and quantity. In terms of access, only few financial institutions serve rural areas in Ethiopia, this leads to low levels of financial inclusion Wikipedia (2017). This study attempts to find out the determinant of access to credit among small scale irrigation user farmers.

\section{Statement of the problem}

Knife et al. (2012) In Ethiopia irrigation covers only 0.16 million ha or about 5 percent of the total irrigable land from 4.5 million ha of potential irrigable land. Most of the farmers dependent on rain fed agriculture, and this made the country's agricultural economy extremely fragile and vulnerable to the impacts of weather and climatic inconsistency. Adugna (2014) Regardless of relatively abundant surface and ground water resources and presence of the four major river basins of the country and Lake Tana, more than 95\% of Amhara Region's agriculture, both crop and livestock sector is dependent on inconsistent and uncertain rainfall.

Different factors contribute for farmers to participate in irrigation; Access to financial services is one of the factors. It can enable smallholders to invest in irrigation technology. Joseff and Maren (2008). Kinfe et al. (2012) Adugna (2014) and Gebremedhin (2015) the key constraints hindering the success of small scale irrigation are financial shortage; Poor economic background of users for irrigation infrastructure development; to access irrigation technologies and agricultural inputs. Agerie (2014) and Muez (2016) access to credit is one of the important determinants for participating in small scale irrigation and there is systematic association between irrigation participation and credit access. Diogo and Lisa (2015) A number of NGOs (non-governmental organizations) and MFIs (micro finance institution) work with small-scale farmers to help them secure financing 
for irrigation pumps and equipment, but even these have limited capacity.

Yusuf et al. (2016) review different studies on the determinants of demand for credit and found that most of the findings are inconclusive, due to the contextual, socio-economic, geographical, environmental and other variations across the study areas. And the paper call the need for more empirical studies on the determinants of credit for a specific region for better policy that may be suitable for that particular region. So, it is rational to validate this study the factors that affect small scale irrigation user farmers' access to formal credit with particular reference to Dangla woreda farmers. This paper try to answer the following questions what factors affect small scale irrigation user farmers' access to formal credit; challenges of formal financial institutions in the study area and how the revolving fund approach is helpful to fill gaps related to access of irrigation credit.

\section{Objectives Of The study \\ 3.3.1 General Objective}

- To examine the factors that affect access to credit among small scale irrigation user farmers.

\subsubsection{Specific Objectives}

1. To identify factors that affect small scale irrigation user farmers access to formal credit.

2. To assess the constraints to access credit from formal financial institutions.

3. To Explain how the revolving fund approach is helpful to access irrigation credit.

\section{RESEARCH METHODOLOGY}

\subsection{Data Source and Method of Data Collection}

Primary data collected from small scale irrigation user farmers and from creditors. Secondary data was collected from literature, books, office of agriculture, Amhara credit and saving institution (ACSI), farmer's multipurpose cooperatives and savings and credit cooperatives. The primary data collected from small scale irrigation user farmers by using structured interview and primary data collected from creditors using key informant interview.

\subsection{Model Specification}

The Linear probability model is plagued by several problems, such as; non-normality of error term, heteroscedasticity of error, probabilities lying outside the $0-1$ range, and the generally lower $\mathrm{R}^{2}$ values. But these problems are manageable. But even then the fundamental problem with the LPM is that it is not logically a very attractive model because it assumes that $\mathrm{Pi}=\mathrm{E}(\mathrm{Y}=1 \mid \mathrm{X})$ increases linearly with $\mathrm{X}$, that is, the marginal or incremental effect of X remains constant throughout Gujarat (2004).

Due to the above problems of LPM the analysis of this study has to be made by logit or probit models. Sisay (2008), Joyce.C et al. (2015) and Ololade et al. (2013) Uses logit model to examine the determinants of smallholder farmers' access to formal credit. Tran Thi et al. (2015) studied Determinant of Access to Rural Credit and Its Effect on Living Standard using Probit and Tobit models. Probit model is used to determine the factors affecting probability to require formal credit by the poor. Tobit model studies the relationship between the degrees (quantity) of dependent variables fluctuate with the independent variables. And use to investigate the factors that affect the loan amount of poor households. Benjamin et al. utilized Heckman selection model and Probit model to determine Factors influencing smallholder farmers' access to agricultural microcredit in Northern Ghana the Heckman selection model was chosen as the analytical tool for addressing the possible presence of sample selectivity bias in the loan size regression.

Therefore, the cumulative logistic probability model is econometrically specified as follows: $\mathbf{P i}=\mathrm{F}(\mathrm{Zi})=\mathrm{F}\left(\alpha+\sum \mathrm{B}_{\mathrm{i}} \mathrm{X}_{\mathrm{i}}\right)=1 / 1+\mathrm{e}^{-\mathrm{z}}$

\section{RESULTS AND DISCUSSION}

\subsection{Model specification and goodness of fit test}

\subsubsection{Model specification test}

The Stata command linktest is used to detect a specification error. The hat is statistically significant predictor at $1 \%$ significance level and the variable hatsq is insignificant. It implies that model has no specification error.

\subsubsection{Goodness of fit test}

The p-value is 0.98 it is large and it indicates that the model fit good.

\subsubsection{Multicollinearity diagnosis}

All the explanatory variables have no serious multi-colinearity problem. The data were found to have no serious Problem of multi collinearity and therefore the variables were retained in the model.

\section{Model output}

Thirteen variables were hypothesized to explain factors affecting smallholder farmer's access to formal credit. Out of these six of the variables were found to be significant, while multipurpose cooperative membership and extension package participation excluded from the model, because two variables did not show variation among 
sample farm households. And the other five were less significant in explaining the variations in the dependent variable.

The maximum likelihood estimates of the logistic regression model show that cost of irrigation technology (irrcost), income from irrigation (irrincome), lending procedures (dlend), repayment period (drepayment_period), age of the household (age) and livestock ownership (livestock_ownership) were important factors influencing smallholder farmers access to formal credit in the study area.

The demographic variables education and sex, and distance from the institution, risk and monthly saving were less powerful in explaining smallholder farmers' access to formal credit indicating that the two groups were homogeneous with regard to these variables.

TABLE: 4. 1 MAXIMUM LIKELIHOOD ESTIMATES OF LOGIT MODEL

\begin{tabular}{rcccc}
\hline creditaccess & Coefficients & Std. Err. & $\mathrm{z}$ & $\mathrm{P}>|\mathrm{z}|$ \\
\hline IRRCOST & .00113 & .0002 & 4.28 & 0.000 \\
SEX & .40903 & 1.0487 & 0.39 & 0.697 \\
RISK & 2.3702 & .7873 & 3.01 & 0.003 \\
IRRINCOME & -.00172 & .0005 & -2.90 & 0.004 \\
LENDING PRO & -3.0905 & .8863 & -3.49 & 0.000 \\
REPAYMENTPERIOD & -3.4194 & .9142 & 3.74 & 0.000 \\
SECONDARY & -1.8580 & 1.351 & 1.37 & 0.169 \\
PRIMARY & .31098 & .9327 & 0.33 & 0.739 \\
WRITEREAD & .16986 & .9074 & 0.19 & 0.852 \\
AGE & -.1091 & .0496 & -2.20 & 0.028 \\
MONTHLY SAVING & .00260 & .0030 & 0.84 & 0.399 \\
LIVESTOCK & .25516 & .1146 & 2.23 & 0.026 \\
DISTANCE & -.4203 & .4513 & -0.93 & 0.352 \\
cons & 1.9950 & 2.474 & 0.81 & 0.420
\end{tabular}

Number of obs $=329$

$\operatorname{LR} \operatorname{chi} 2(13)=234.01$

Prob $>$ chi2 $=0.0000$

Log likelihood $=-34.667876$

Pseudo R2 = 0.7714

source: Computed fromthe field survey data, 2009

6.1 Discussion on significant explanatory variables

TABLE: 4. 2 MARGINAL EFFECT AFTER LOGIT ESTIMATION

\begin{tabular}{rlllc}
\hline Variable & $\mathrm{dy} / \mathrm{dx}$ & Std. Error & $\mathrm{z}$ & $\mathrm{P}>|\mathrm{z}|$ \\
\hline IRRCOST & $.00001^{* * *}$ & .000 & 4.28 & 0.000 \\
SEX & .00330 & .007 & 0.43 & 0.669 \\
RIDK & .04396 & .030 & 1.43 & 0.153 \\
IRRINCOME & $-.00001^{* * *}$ & .000 & -2.90 & 0.004 \\
LENDING & $-.07685^{*}$ & .044 & -1.72 & 0.085 \\
REPAYMENT & $-.08967^{*}$ & .047 & -1.90 & 0.057 \\
SECONDARY & -.00911 & .007 & -1.26 & 0.208 \\
PRIMARY & .00305 & .009 & 0.31 & 0.757 \\
WRITEREAD & .00161 & .008 & 0.18 & 0.857 \\
AGE & $-.00101^{* * *}$ & .000 & -2.20 & 0.028 \\
SAVING & .00002 & .000 & 0.84 & 0.399 \\
LIVESTOCK & $.00237^{* *}$ & .001 & 2.23 & 0.026 \\
DISTANCE & -.00391 & .004 & 0.93 & 0.352
\end{tabular}

source: Computed from the field survey data, 2009.

$* * *$ represent level of significant at $1 \%, * *$ represent level of significant at $5 \%$, *represent level of significant at $10 \%$.

Cost of irrigation technology (irrcost) was found to be an important variable in accessing formal credit use. Cost of irrigation technology positively affects access to credit. The P-value corresponding to the variable irricost show that it is significant at $1 \%$ level. But, its effect is negligible. The increase in a birr cost of irrigation increase the probability of access to credit by 0.001 percent, but it is almost 0 . The explanation is that when the cost of irrigation technology is high the farmers can't afford the price and need other financial sources. This was consistent with the prior expectation.

Income from irrigation (irrincome) was also another factor which was significantly related to the dependent 
variable and that it was significant at $1 \%$ level. It negatively affects access to credit. The increase in income from irrigation by one birr, decrease the probability of access to credit by 0.002 percent. This is inconsistent with the prior expectation and also its effect was negligible, this is because, most of the households who have a higher income from irrigation had small scale irrigation technology by their own finance, and the use of technology also makes their income higher.

Lending procedures such as peer group formation, project proposal and other written applications and collateral hypothesized to have a negative relationship with access to credit, because farmers don't want to put their asset on risk, the peer group formation also difficult especially for poor farmers and farmers didn't know how to prepare of project proposal. It was significant at $10 \%$ level and the result is consistent with the prior expectation. The result of the logit mode revealed that lending procedure has a negative relationship with access to credit. Households who constrained by lending procedures than households who are not constrained by lending procedures the probability of access to credit decrease by 8 percent.

This study is consistent with John et al. (2014) who empirically tested Factors Influencing Access to Credit Services by Women Entrepreneurs, found that majority of the women entrepreneurs does not access credit from financial institutions because of lack of friendliness in the lending procedures and also Lending procedures were found to be rigid and does not accommodate the needs of women entrepreneurs. The study by Francis (2015) on Small Scale Sugarcane Farmers also indicated that the lending terms and conditions prevent Small Scale Sugarcane Farmers from seeking credit.

This study is also consistent with the study by Sisay (2008) on determinants of smallholder farmer's access to formal credit in metema woreda found that collateral or group formation was highly important in influencing access to formal credit.

Repayment period (drepayment period) is also another variable which has a significant relationship with the dependent variable access to credit. It was affects access to credit negatively. It was hypothesized to have a negative relationship, because ACSI the repayment period for agricultural credit is short which is one year in the credit institutions and it may be in the production month (on summer), and farmers can't repay the credit during that period. It is significant at $10 \%$ and the result from the model also consistent with the prior expectation. Households who constrained by Repayment period than households who are not constrained by Repayment period the probability of access to credit decrease by 9 percent.

This study is consistent with Sunday et al. (2013) who empirically examined the Determinants of Credit Access and Demand among Poultry Farmers using Independent double hurdle model was aimed determining factors influencing credit accessibility and demand among poultry farmers. The result from the model revealed that, the amount of loan demanded by the poultry farmers was significantly influenced by the loan repayment period.

Number of livestock (number of livestock in tropical livestock unit) (livestock population) in the rural areas constitutes accumulation of wealth, security against emergencies, and also used as a cultural privilege. It was hypothesized to have a negative relationship with the dependent variable by justifying, as the total number of animals in the household increase; the household source of income also increase. This variable is significant at $5 \%$, the result of the logit model also revealed that the variable has a positive relationship with access to credit. Farmer with large number of animals' uses formal credit than with lesser animals. Increase in number of livestock by one increases the probability of access to credit by 0.2 percent. The result is inconsistent with the prior expectation.

The result was inconsistent with Awotide et al. (2015) studied the impact of access to credit on agricultural productivity using the Endogenous Switching Regression Model and found that Total livestock unit is negative and statistically significant in determining the farmers' access to credit. This result was also inconsistent with Sisay (2008) which reveals that number of animals has a negative relationship, that farmer with lesser number of animals uses formal credit than with larger animals.

The positive relationship of livestock population with access to credit in the study area could be due to the livestock required as collateral to get credit, so households who had larger number of livestock or value off livestock will more likely to access credit.

Age of the farm household also another significant variable; it is significant at $5 \%$ significance level. The prior expectation was that farmers with higher age may have more access to use credit from the formal sources, but the result is inconsistent with prior expectation. Age of the farm household affects access to credit negatively. A one year increase in the age of a household decreases the probability of access to credit by 0.01 percent.

The study by Paul M. (2008) Constraints in Access to and Demand for Rural Credit in Uganda The study used the Uganda household surveys. probit, tobit and multinomial logit model estimations was applied. The result revealed that educated and the young are more likely to demand credit.

The result is inconsistent with Akudugu (2012) who estimates the determinants of credit using Logit and Tobit models. The result reveals that age have significant positive effects on credit demand. The result is also inconsistent with Ma-azu (2015) studied determinants of access to credit and its impact on household food security in karaga district of the northern region of Ghana. The study employed multivariate tobit model that 
estimated the determinants of credit. The study revealed that age positively affect access to credit.

\subsection{The Importance of Revolving Fund on Irrigation}

Revolving Fund is that an organization or sometimes an individual has a reserve of money (the Fund) which is used to lend to one or more borrowers. Over a given period of time, the borrower is expected to repay the original sum that restocks the fund. Usually, an additional sum is charged (interest) to the borrower that acts as a fee for providing the service (administrative costs) and it helps to protect the fund from being depleted. Factors contributing to depletion can include inflation, non-payments (low rate of repayment) and the cost to the lender of getting outside finance.

Revolving Funds is often used in developing countries like Ethiopia to provide affordable access to credit for those wishing to borrow money for anything from buying food and productive inputs, to businesses and services.

There are two types of revolving fund; formal and informal revolving funds.

The main differences between an informal rotating credit scheme and a formal revolving fund, is the source of the initial fund, the scale of lending and the structure of the credit management.

Informal funds are usually those found in developing countries at the local or community level, in poor areas where access to formal bank credit is virtually impossible. Members of a group put their savings into a commonly held fund, which is then lent to other members when they need a loan. Informal revolving funds do not usually earn any interest, unlike more formal schemes.

An important feature of such schemes is that they depend on social organization to ensure loans repayment. Peer or group pressure is a critical aspect of this kind of fund as it is used to ensure repayment, improve understanding between group members and can also be used to strengthen social networks. These types of funds are based on community savings.

A formal revolving fund usually uses seed money from an outside organization or agency. The capital fund is managed by a local organization or NGO and not the community themselves.

The seed money is used to pay for the operational structure (buildings, office equipment and vehicles for example) and also to loan money to many small borrowers. Repayments by the original borrowers over an agreed period of time, puts money back into the fund for other people to borrow. If managed well, revolving funds are an excellent means of making affordable credit available to the poor and with a small amount of capital can help benefit many people.

The concept of formal revolving funds has recently been replaced with the concept of micro-finance, which incorporates many different elements of providing small amounts of money to a large number of people.

In the study area there are non-governmental organizations providing the revolving fund, to support irrigation, animal fattening, and bee. According to the dangeshta kebele FMSC the revolving fund is distributed to the farmers through them and they have the power to control the money and recirculate the fund. More than $80 \%$ of the sample household who had access to credit is beneficiary of this revolving fund.

According to the Gumdire kebele FMSC; the non-governmental organizations provide the Revolving fund only for animal fattening and bees and there is no any special type of irrigation financing in the kebele.

According to the FMSCs, in the study area FMSCs mainly provide farm input; fertilizer and seeds and almost all farmers are member of the cooperative, because non-member farmers can't get seed, fertilizer and other benefit. So, it is easy for them to access the farmers.

The respondents who get a credit from the revolving fund benefited in different aspects; lower interest rate charge for the revolving fund, it is less than half of the interest rates charged by FMSC and ACSI, which is $7.25 \%$.

Longer repayment period and time of the revolving fund; repayment period and time is very long and convenient for the farmer. The farmers required to repay the loan for three years, but in ACSI and FMSC credit should be repay within one year. The repayment time of the loan for this is not limited, farmers can repay at any month with in the year.

Other importance of revolving fund indicated by FMSC is it is women oriented. Non-governmental organization mainly works on women empowerment and they give special opportunity for women.

\section{CONCLUSIONS AND RECOMMENDATION}

\subsection{Conclusion}

This study was focused on the factors that affect irrigation user farmers' access to formal credit. A multi stage sampling technique was employed to select the respondents. A total of 329 respondents were selected, the data was collected using interview questionnaire. The study used logistic regression method to estimate factors affecting access to credit.

The logistic regression analysis results show that among thirteen explanatory variables, which were included in the model, only six variables were statistically significant while the remaining five were less significant in 
explaining the variations in the dependent variable and multipurpose cooperative membership and extension package participation excluded from the model, because two variables did not show variation among sample farm households.

The analysis shows that the probability of accessing formal credit was positively and significantly affected by cost of irrigation technology and number of livestock in TLU. Income from irrigation, repayment period, age, and lending procedures negatively affect access to credit.

based on the data from the interview questionnaire, peer group (trust group) collateral, repayment period and time, interest rate, loan size (loan amount) constraint or challenges that farmers faces in the study area.

In the study area FMSC participating on revolving fund, non-govenmental organization provide the revolving money to FMSC. According to the FMSCs it benefit the farmers, by lower interest rate, longer repayment period, and it gives special opportunity for womens.

\subsection{Recommendation}

To increase the importance of irrigation and technology adoption of the farm households, there should be some sort of credit access that target at irrigation or institutions should prepare a sepcial credit program for irrigation.

The repayment period of the FMSC and ACSI should be long and the repayment time should correspond to period of cash availability for the poor households.

In the study area the revolving fund supplied by the non-government organization and it is not adequate. Government plans to reduce poverty and irrigations is one means of poverty reduction. So, to achieve this plan government should also participate on revolving fund supply.

\section{REFERENCE}

Aduga, E. (2015) Five key Constraint to Small Scale Irrigation Development in Ethiopia. Journal of Management and Business Studies, Vol.13, No.10, 441-444.

Agerie, N. (2016) Determinants of small holder rural farm house hold participation in small scale irrigation and its effect on income in north Gonder zone. Journal of Innovative Research and Development, Vol. 5

Akudugu, A. (2012) Estimation of the Determinants of Credit Demand by Farmers and Supply by Rural Banks in Ghana's Upper East Region. Journal of Agriculture and Rural Development, Vol.2, No.2, 189-200.

Bawotide, A, Abdoulaye, T, Alene, A and Manyong, V. (2015) Impact of Access to Credit on Agricultural Productivity: Evidence from Smallholder Cassava Farmers in Nigeria.

Benjamin, Stefan and Jukka. (2015) factors influencing smallholder farmers access agricultural microcredit in northern Ghana. Journal of Agricultural research, Vol. 10, no.2460-2464.

Derejie and Desale.(2016) Assessment of the Impact of Small Scale Irrigation on household Livelihood Improvement; at Gubalafto district, Unpublished Msc thesis.

Desta, B. (2004) Impact of Community Managed Irrigation on Farm Efficiency and Household income; the case of Weliso and Wenchi Districts of Oromia, Unpublished M.Sc Thesis, Haramaya University.

Diogo, M and Lisa, P. (2015) Ethiopia Irrigation Market Brief.

FAO. (2003) Irrigation in Africa South of the Sahara, FAO Investment Center Technical Paper 5, FAO: Rome.

Francis. (2015) the factors that affect accessibility to credit services by small scale sugar cane farmer; in Kenya, unpublished, developing countries studies,vol.5.

Gujarati. (2004) Basic Econometrics, Fourth Edition, McGraw-Hill Companies.

John.G, Anthony.k Samuel.k.(2014) analysis of factors influencing access to credit services by women entrepreneurs in Kenya. Journal of Finance and Accounting, Vol. 5.

John, K, Kuwornu, M, Isaac, D, Ohene, N and Samuel, A.(2012) Agricultural Credit Allocation and Constraint Analyses of Selected Maize Farmers in Ghana. British Journal of Economics, Management \& Trade, vol. 2 , No.4, 353-374,

Josef and Maren. (No date) financing small scale irrigation in sub-Sahara Africa.

Knife, A., Chilot, y. and Sundar, R. (2012) effect of small scale irrigation on the income of rural fram household: the case of laelay maichew district centray tigray, Ethiopia agricultural series, vol.7.

Knife, A. (2012) Irrigation versus rain fed agriculture driving for household income disparity, a study from central tigray, Ethiopia. Journal of Agriculture science research, vol.2, No.1, 20-29

Kuwornu, J., Ohene, N., and Asuming, S. (2013) Agricultural Credit Allocation and Constraint Analyses of Selected Maize Farmers in Ghana. British Journal of Economics, Management and Trade, Vol. 2, No.4, 353-374.

Ma-azu, Abdul. (2015) determinants of access to credit and its impact on household food security in karaga district of the northern region of Ghana.

Olaf, V. (2011) Small-Scale Irrigation in Amhara Region of Ethiopia.

Paul, M.(2008) Constraints in Access to and Demand for Rural Credit: Evidence from Uganda.

Seleshi, B. (2010) Irrigation potential in Ethiopia. 
Sisay, Y. (2008) determinants of small holder farmers access to formal credit in the case of metema woreda.

Tran. T, Nguyen, Q. and Hoang, H. Determinants of access to credit and its effect of living standard in northwest Vietnam. International Journal of Financial Research, Vol. 6, No. 2.

Wikipedia. https://en.wikipedia.org/wiki/Agriculture in_Ethiopia (accessed on 2017).

Yusuf, I., Shri, D and shallahuddin. (2016) Determinants of demand for credit a conceptual review. Journal of Economics and Empirical Research, Vol.3, No. 6-10. 